
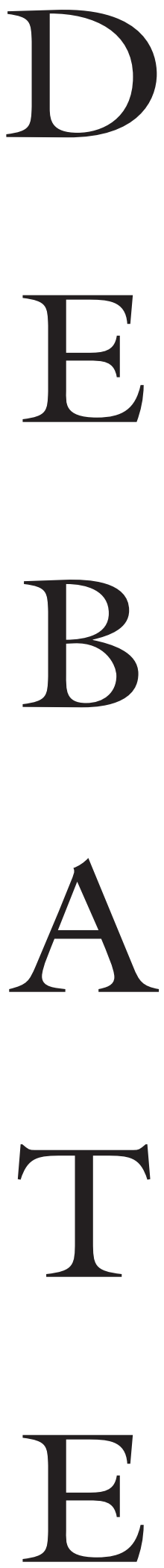

In this issue of Kvinder, Kon \& Forskning the debate article concerns child adoption in developing countries and it touches upon the complex and conflictual nature of sense of belonging. Maj Eun Herlow, who herself as a child was adopted from Korea, discusses from a personal standpoint how adoptees from developing countries raised in the West perceive returning to their country of origin.

On behalf of the debate team, Ditte Find Moller

\section{PERSPECTIVES ON INTERNATIONAL ADOPTION FROM SOUTH KOREA}

\section{By Maj Eun Herløw}

$\mathrm{T}$ he story about me and my sister before we were adopted to Denmark is a story of origin about a poor Korean family with seven children. About how our father died of stomach cancer in his late $40 \mathrm{~s}$ and how our mother was no longer able to support the entire family. The youngest of the children was also the only boy, and he stayed in Korea, because the in-laws agreed to take him in. The three eldest sisters were able to work and stayed with our mother. The survival strategy of my Korean family was to give up the youngest girls for adoption, and let the remaining siblings work for a salary in order to keep the rest of the family together. This allowed them to survive the hard times. In 1982, the year my Korean family had to send their three youngest girls away for adoption, was paradoxically also the year the Korean economic boom peaked. Over the years this socioeconomic development has brought my Korean family out of poverty and replaced it with the comforts of middle class living.

My sister and I were placed in an orphanage for five months before we were adopted to Denmark. My sister was six and I was four years old. We grew up together raised by a couple who were not able to conceive biologically. Sister number three was send to the U.S and became part of a family who adopted both my sister and another girl from Korea when their two grown up biological children no longer lived at home. I learned about her existence, when my sister and I reunited with our birth family in 2003 .

This is my story of origin: a dispersed family scattered across three continents; a story of human suffering; and a Korean state which was the first to export children internationally in times of despair, and continues to do so in times of prosperity. Over the years this practice has become a physical bond for the Korean state with its Western allies, due to the demand for children in Western countries. This bond between Korea and countries in the Western world is the point of departure for my discussion of the complexities of belonging experienced by adult adoptees when they return to 
Korea to explore their lost identity.

The history of international adoption from South Korea began in the aftermath of The Korean War from the mid 1950s and onwards. The estimated number of children adopted from Korea to Western countries since the 1950 s is beyond 200.000. The largest group (approximately 150.000 children) was sent to American families and the remaining to European and Australian families. On a global scale this amounts to one third of the world's internationally-adopted children. Since the transition from military dictatorship to democracy in South Korea in 1989, adult Korean adoptees have returned in increasing numbers, reclaiming rights in their birth country. Their efforts have rewarded them the right to obtain dual citizenship in Korea alongside the nationality of the adoption country taking effect in 2011 . However, in countries like Denmark it is impossible for adult adoptees to benefit from the legal possibility of dual citizenship, because a single citizenship has to be determined after the age of 18 .

The contributors to the international adoption industry were and still are women in economic and social despair. Throughout the years international adoption out of Korea has been supported by the Korean government. Political decisions have affected the massive transnational adoption out of Korea for more than a decade. Decision making has been motivated by the profi- table adoption industry and furthermore by the prospect of lowering social welfare expenditures. However, the international adoption practice is questioned by Koreans themselves as well as adoptees in times of prosperity and very low birth rates among the Korean population. Child export is an unfortunate image for a country with the third largest economy in Asia, and the $13^{\text {th }}$ largest economy internationally. An adoption practice that was initialized in the post war era has not yet been abandoned even though the economic growth rate in Korea exceeds any Western country.

The dominant research on international adoption has primarily been undertaken from the perspective of the receiving country, which are countries in the Western world. In this research adoptees from Korea have been represented as the most adjustable and easily assimilated group of international adoptees into Western societies. The research made on the adoption practice from a Western perspective barely includes the place of origin, and it has been very uncritical when it comes to the unequal power relations. The adoptees assimilation into Western societies has been the successful version of the story. But suicide rates higher than the average population, and psychological experiences of alienation caused by ethnic difference from the majority population, and by not having any connection to the past origin, show a darker side of the story.

Transnational adoption has become an answer to unwanted infertility in the Western world, and the international adoption agencies morally legitimize a practice based on Christian ideology of helping out the orphaned and abandoned children in the development countries. The Western multiculturalist ideology of the 'rainbow family' furthermore emphasizes international adoption as a dimension of a liberal family construction. However, erasing the importance of the place of origin in international adoption practices has left the adoptees growing up with a half told story of their life, which is likely to develop into difficult issues of identity and belonging during teenage years and adulthood.

\section{THE ADOPTEE VOICES}

In the process of exploring their complex identity the adult Korean adoptees have found a collective voice that is contributing to and challenging the dominant perspectives on international adoption practices. Through political lobbying adult adoptees have successfully demanded post adoption services to be a requirement for international adoption agencies because of the important role which origin plays during the upbringing in Western families. The extensive communities of Korean adoptees in the adoptive countries and in Korea as well as on the internet are all evidence of such phenomena. The long history of Korean adoption has made adoptees come of age, and has made 
them create independent forums to exchange the experience of adoption with other adoptees.

An increasing number of adoptees return to Korea as adults to connect with their place of origin and to explore their ethnic identity - an identity which has been suppressed during the upbringing in adoptive families through the process of assimilation into white middle class families. Approximately 500 overseas Korean adoptees are living in Korea today, and statistics on visits paid to adoption agencies in Korea in 2005 show an estimate as high as 5000 visits. These numbers are evidence of a return phenomenon among Korean adoptees that are not yet seen within other groups of international adoptees.

I went to South Korea in 2006, and did an anthropological fieldwork of the return phenomenon among adult adoptees in the capital Seoul. During the 5 months I lived there, I explored the place I was born on an every day basis, and experienced the complexities of the adoptee encounter with Korean society.

Returning adoptees express their encounter with Korean society as partly positive and challenging; it is a great comfort to suddenly blend in with the majority population because of the experience of ethnic similarity. On the other hand there is a stigma attached to revealing the adoptee background to local Koreans; this challenges the adoptee's own sense of identity and belonging. A Danish female adoptee describes her experience of stigma with the following words:

\section{"The fact that I'm adopted} equals a bad family background. I think I've seen some tendencies... I think it has to do with conceptions of blood relations. I think that some Koreans believe that if you had a mother that gave you up, she exemplifies a bad mother...she cannot even be called a mother! She has a daughter and blood is inherited and health is inberited, which means I'm not good in any of these areas. That's why I can get very angry at my Korean mother because she has put me in this situation. If I want to marry a Korean guy, my chances are really bad".

The Korean notion of personality as inherited by blood is an aspect of stigma that makes it very difficult for the adoptees that returns to live in Korea to blend in with the majority population.

In the Korean context the returning adoptees become individual actors who set out on a personal journey to find a lost identity. This journey ultimately transforms into the challenges of everyday life in a foreign context. A strong sense of Korean belonging develops through the experience of living in the country for some time. This is expressed by an American female adoptee:

\section{"Even though I couldn't com-} municate with people, I felt at ease and a kind of comfort I never experienced in America. I did not even know existed! Now
Korea is home but in the beginning it was more like I had a connection with these people on a level that is beyond family on a kind of a historical level. This is where my people come from! This is where I come from! It's a feeling of history... History is such an important issue for us adoptees because most of us know nothing about our past, and there are huge gaps in who we are, as if our lives didn't begin before we stepped off that plane into our adoptive countries. rour past is erased as if it didn't exist before that. When I came here I felt this is my past, these are my people, and this is where I was born to be raised. This is where I was born to live, and so I never really expected to feel that way, and I think that is probably one of the reasons why I stayed".

\section{RETURNING ADOPTEES -}

A NEWFOUND RESOURCE FOR THE KOREAN STATE

The economic boom in Korea has influenced the political motivation to re-incorporate adoptees into the Korean national narrative. According to the Deputy Director for the Children's Welfare team with whom I did an interview, a special effort is made by the government to reattach the adult adoptees as a resource for Korean society:
"Adoptees are the special ones the government could not take care of in the past, but we take care of them today through eco- nomic support to adoptee orga- nizations and sponsor cultural experiences for adoptees. 
Adoptees should stand up in the world. They are Koreans by blood. Like the kyopos (overseas Koreans) they are a good resource to the Korean society".

Globalization, understood as the flow of information, images and popular culture across national borders, has been very influential in making Korean adoptees around the globe aware of their birth country. Likewise it has made it possible for the Korean state to reach out, and communicate the needs of its ethnic nationals beyond its borders. The interest of the state in return migration from its overseas ethnic nationals or descendants of former nationals, lies in the demand for labour which was caused by economic growth.

Korea's economic prosperity has indeed been a motivational factor for the adoptees, who have returned to live in Korea because of the many possibilities available in a country with a fast paced urban and techno- logical development. This is also why English language skills are in great demand and English tutoring is the main and very well paid profession of the majority of adoptees living in Korea. It is a demand that exemplifies the ambition of South Korea to strengthen their position in the global market.

The returning adoptees encounter both the inclusive acceptance of the Korean state, and the marginalization made by local Koreans, which makes them even more aware of their foreignness. The adoptees' response to this reality is to develop a situational identity, which is a social strategy of interaction by situationally emphasizing or downplaying the Korean, the adoptee or the Western identity. The adaptation into Korean society is therefore a constant negotiation to legitimize the complex identity that makes the adoptees realize that they do not belong exclusively to either the adoptive country or their country of birth. Over time the sense of belonging transforms into alternative belongings, which means the adaptation of identity to the social situation of interaction. When adoptees become aware of the fact that their identity is situated in between two worlds, they transform this realization into advantages of ethnic empowerment as a group as well as into individual agency.

Korean adult adoptees are the first group of international adoptees who resettle in their country of birth. They are an example of a new group of return migrants that seek out new opportunities and encounter alternative identities as a result of human migration between development countries and the Western world one out of the many faces of globalization.

Maj Eun Herløw, cand.scient.anth. 